\title{
MEMULAI MENJADI ENTREPRENEUR
}

\author{
Munif Efendi \\ Institut Agama Islam Bani Fattah Jombang, Indonesia \\ munifefendi@iaibafa.ac.id
}

\begin{abstract}
Abstrak: Niat dan keyakinan melakukan segala usaha pekerjaan semata-mata mencari keridloan Allah. Implementasi teori entrepreneur (kewirausahaan) pada dasarnya adalah suatu usaha yang dilakukan melalui pengawasan melekat oleh diri sendiri melalui kreatifitas inovasi berkarakter untuk mencapai kemanfaatan hidup. Menyadari kekurangan ada usaha belajar dengan komitmen. Memulai menjadi entrepreneur koreksi mempersiapkan perilaku dengan mengimplementasikan kajian teori meliputi kesimpulan pendapat yaitu; (1) Niat dan keyakinan, memiliki kesadaran mengerjakan tugas dengan tanggung jawab dan berusaha menyelesaikan, bahwa ia mampu. (2) Sadar akan kemampuan, berorientasi membaca peluang, mempelajari proses tahapan kesuksesan yang dapat dibuat kajian. Mawas diri dan tidak membesarkan diri dengan segala kemampuan berjalan menyesuaikan dengan kesesuaian. (3) keinginan belajar, memahami kebutuhan dan layanan terhadap konsumen, mengikuti pasar dalam kesesuaian produk baru. (4) Komitmen melalui tahapan dan evaluasi untuk menyusun strategi baru, mengontrol kebijakan strategi,
\end{abstract}


menganalisa kesesuaian secara periodik untuk mengefektifkan dan memperkecil resiko.

Kata Kunci: awal, Entrepreneur, Niat.

\section{PENDAHULUAN}

Kesuksesan pelaku kewirausahaan menjadikan inspirasi, sedangkan kegagalan pelaku kewirausahaan menjadikan momok menakutkan. Keraguan untuk memulai menjadi pelaku kewirausahaan, banyak yang menunda karena memastikan langkah aman. Menjadi diri sendiri, menjadikan karakter personal dan organisasi yang menjadi pembeda dengan lainnya. Suatu nilai dasar akan muncul sebagai kreator yang inspiratif yang memiliki inovasi beda sebagai nilai yang tidak dimiliki individu atau organisasi lainya. Kemunculan aktor tersebut akan terlihat dan ternilai serta akan dipandang, oleh organisasi sebagai penentu kebijakan yang unggul.

Teori entrepreneur merupakan suatu sistem general yang dapat diimplementasikan keilmuannya dalam berbagai bidang. Sebagaimana pendapat Zimmerer, Kewirausahaan adalah suatu proses penerapan kreativitas dan inovasi dalam memecahkan persoalan dan menemukan peluang untuk memperbaiki kehidupan ${ }^{1}$. Menurut Soeharto Prawiro Kewirausahaan adalah suatu nilai yang diperlukan untuk memulai suatu usaha (start up phase) dan perkembangan usaha (venture growth) ${ }^{2}$. Sedangkan menurut Suryana, Kewirausahaan (Entrepreneurship) adalah kemampuan kreatif dan inovatif yang dijadikan dasar, kiat, dan sumber daya untuk mencari peluang menuju sukses ${ }^{3}$. Menurut Mulyasa: wirausaha adalah orang yang dapat meningkatkan nilai tambah terhadap sumber tenaga kerja, alat, bahan dan aset lain serta orang yang memperkenalkan perubahan, inovasi dan cara-cara baru ${ }^{4}$. Suatu usaha akan terpacu dengan kreatifitas pada awal dan perkembangannya dengan kemampuan memberikan nilai tambah dalam organisasi. Adanya kreatifitas dan nilai tambah memberikan kontribusi pada hasil inovasi yang dijalankan sehingga memiliki pembeda dengan yang lainya memberikan nilai daya tarik organisasi yang beda pula.

Pandangan Islam terhadap kewirausahaan merupakan pandangan mu'amalah, berhubungan dengan pandangan hidup vertikal sebagai

\footnotetext{
${ }^{1}$ Kasmir, 2013. Kewirausahaan, Jakarta: PT. Rajawali Press, hlm. 20.

2 Suryana. 2003. Kewirausahaan: Pedoman Praktis, kiat dan Proses Menuju Sukses. Jakarta: Salemba Empat. hlm.13

${ }^{3}$ Ibid, hlm. 3

4 E. Mulyasa, 2007. Standar Kompetensi dan Sertifikasi Guru. Bandung: PT. Remaja Rosdakarya: 179
} 
individu dan berbersifat horizontal antar manusia yang menjadikan pertanggung jawaban dunia akhirat. Allah SWT mengingatkan kepada manusia sebagaimana dalam kitabnya yang Artinya: "Dan babwa manusia hanya memperoleh apa yang telah diusabakannya, dan sesunggubnya usahanya itu kelak akan diperlibatkan (kepadanya), kemudian akan diberi balasan kepadanya dengan balasan yang paling sempurna, dan sesungguhnya kepada Tubanmulab kesudahannya (segala seuatu)". ${ }^{5}$ Hasil kreativitas menjadi inovasi menjadikan amalan, karena memiliki nilai manfaat bagi kosumsi atas manfaat yang menyertai. Seberapa besar nilai manfaat yang terkandung, yang memiliki kemampuan melihat dan tahu adalah pembuat produk tersebut, ketika produk yang dihasilkan baik maka akan mendapat amalan baik begitu pula ketika buruk maka akan menjadikan amalan buruk baginya, dan akan menjadikan pertanggung jawaban dunia akhirat.

Konsep kewirausahaan juga diulas lebih rinci oleh Ciputra, yang membuat batasan katagori dari konsep kewirausahaan. Ada empat katagori entrepreneur yang akan membedakan batasan katagori entrepreneur, yaitu: (1) Business Entrepreneur dibagi menjadi dua; (a) Owner entrepreneur adalah para pencipta dan pemilik bisnis, (b) Professional entrepreneur adalah orang-orang yang memiliki daya wirausaha namun mempraktikannya di perusahaan milik orang lain. (2) Government Entrepreneur, seorang atau kelompok orang yang memimpin serta mengelola lembaga negara atau instansi pemerintahan dengan jiwa dan kecakapan wirausaha. Sebagai contoh adalah Lee Kuan Yew, mantan Perdana Menteri Singapura, ia adalah seorang pemimpin yang mengelola dan menumbuhkan Singapura dengan jiwa dan kecakapan wirausaha. (3) Social Entrepreneur Yaitu para pendiri organisasi-organisasi sosial kelas dunia yang menghimpun dana masyarakat untuk melaksanakan tugas sosial yang mereka yakini. Dan (4) Academic Entrepreneur, Ini menggambarkan akademisi yang megajar atau mengelola lembaga pendidikan dengan pola dan gaya entrepreneur sambil tetap menjaga tujuan mulia pendidikan ${ }^{6}$.

Entrepreneur (kewirausahaan) merupakan suatu proses implementasi kreativitas dan inovasi untuk menyelesaikan permasalahan dan menemukan peluang memperbaiki menjadikan solusi produk baru yang bermanfaat. Dari pendapat para ahli konsep entrepreneur dikatagorikan menjadi empat yang memiliki lima katagori, untuk melihat lebih dekat dijelaskan sebagai berikut (1) Kewirausahaan Pencipta dan pemilik organisasi bisnis, (2) Kewirausahaan Profesional yaitu pekerja yang memliki jiwa kewirasahaan, (3) Kewirausahaan Organisasi Pemerintahan,

\footnotetext{
${ }^{5}$ QS. An Najm (53): 6

${ }^{6}$ Ciputra, 2008. Entrepreneurship Mengubah Masa Depan Bangsa, Jakarta: PT Elex Media Komputindo. hlm. 8-10
} 
yaitu seorang atau kelompok orang yang memimpin serta mengelola lembaga negara atau instansi pemerintahan dengan jiwa dan kecakapan wirausaha (4) kewirausahaan sosial yaitu pendiri organisasi sosial yang memiliki jiwa kewirausahaan, (5) Kewirausahaan akademik yaitu menggambarkan akademisi pengajar atau pengelola lembaga pendidikan dengan pola dan gaya kewirausahaan yang tetap menjaga tujuan mulia pendidikan. Dari lima katagori memberikan pemahaman bahwa konsep kewirausahaan merupakan suatu sistem Kewirausahaan yang memiliki makna suatu kemampuan yang berakar dari dalam diri, yang bergerak atas kesadaran bukan pengawasan ataupun tekanan. Kewirausahaan merupakan suatu usaha dengan ketulusan memberikan yang terbaik dari kreatifitas inovasi hasil karya untuk kemanfaatan umat.

Kewirausahaan bersifat umum di segala bidang sesuai pijakan, dalam usaha mandiri, sebagai profesional kerja organisasi bisnis, pemerintahan, akademisi dan organisasi sosial. Teori kewirausahaan merupakan serangkaian ilmu pengetahuan yang dapat dipelajari sebagai acuan pemahaman berkarakter dan terintegritas. Teori kewiausahaan mendorong perilaku aktifitas menjadi terampil, dasar dari terampil adalah dengan membiasakan mengerjakan sesuatu secara mandiri yaitu melakukan aktifitas kerja dengan sukarela dan tulus ingin menghasilkan karya lebih, yang memiliki kemanfaatan. Memulai menjadi entrepreneur muncul pada individu karena adanya kemandirian berkarya, selalu berorentasi pada capaian hasil dan memberikan yang terbaik dari hasil karyanya untuk kemanfaatan umat.

Menurut Johan Hasan, salah satu fasilitator UCEO dalam bukunya seri Entrepreneur Kelas Dunia, setidaknya ada empat hal yang membuat seseorang menjadi Entrepreneur. Pertama, mereka memutuskan untuk memiliki visi menjadi seorang Entrepreneur. Mungkin suatu ketika di masa lalu, mereka terinspirasi oleh seorang entrepreneur sukses atau mengalami sebuah pengalaman hidup yang menggugah, atau menemukan ide luar biasa yang memiliki nilai jual. Kedua, mereka mengembangkan ide kreatif sedemikian rupa sehingga ide tersebut memiliki nilai pasar yang kita sebut sebagai inovasi. Ketiga, mereka mewujudkan ide kreatif tersebut dalam sebuah usaha bisnis. Keempat, seorang Entrepreneur berani mengambil resiko yang telah diperhitungkan. Oleh karena mereka sadar akan resiko, maka kegagalan dan resiko yang ditanggung bukan lagi menjadi alasan untuk berhenti mencoba ${ }^{7}$. Memulai menjadi entrepreneur tidak harus menunggu waktu yang tepat, karena terkadang waktu yang tepat itu sudah tergeser kesempatan oleh yang lain. Terkadang waktu dan situasi kurang tepat, tetapi bisa mengkondisikan dengan layanan yang

\footnotetext{
${ }^{7}$ http:/ / ciputrauceo.net/blog/2013/10/5/empat-karakter-entreprenuer
} 
tepat menjadikan kesempatan emas. Memulai menjadi entrepreneur dimulai dengan Niat dan keyakinan yang dimbangi dengan kesadaran akan kemampuan. Keinginan belajar akan dapat melengkapi kekurangan yang disertai komitmen melalui tahapan dan evaluasi untuk memperbaiki kesalahan dari kebijakan dan realisasi.

\section{METODE PENELITIAN}

Metode yang digunakan dalam penulisan ini ialah metode pustaka (library research). Metode digunakan untuk mengetahui keabsahan sebuah penelitian, dengan menggunakan berbagai teknik. Dalam penulisan ini penulis menggunakan metode kualitatif. Dalam penelitian kualitatif instrumennya adalah orang atau buman instrument, yaitu peneliti itu sendiri. Untuk dapat menjadi instrumen, maka peneliti harus memiliki bekal teori dan wawasan yang luas, sehingga mampu bertanya, menganalisis, memotret, dan mengkonstruksi situasi sosial yang diteliti menjadi lebih jelas dan bermakna. ${ }^{8}$. Kajian penulis membandingkan pengalaman kewirausahaan dan observasi dari beberapa pelaku kewirausahaan dengan kajian teori-teori membuat suatu kesimpulan dengan mendiskripsikan. Kesimpulan yang dihasilkan, nerupakan kajian pemaparan padangan yang riel dengan gagasan menurut persepsi penulis. Penulis berusaha menginterprestasikan gagasan dan berpendapat.

\section{HASIL PEMBAHASAN}

Ajaran Islam tentang nilai-nilai hidup yang utama meliputi semua aspek kehidupan manusia secara utuh, tidak ada satu sisi pun dari kehidupan manusia yang hanya berorientasi kepada pemenuhan kenikmatan duniawi semata. Setiap bentuk mu'amalah dari yang paling kecil sampai yang besar, termasuk masalah ekonomi sekalipun, adalah bersifat spiritual, bila di laksanakan sesuai dengan nilai-nilai ini adalah mutlak perlu'. Pemahaman eknomi Islam segala usaha dalam berkarya merupakan bentuk amalan yang memiliki sifat spiritual, yang memiliki maksud yang terkandung, realitanya adalah segala sesuatu pekerjaan tidak luput dari pengawasan Allah. Bekerja tanpa pengawasan melakukan yang terbaik dan memiliki kemanfaatan terhadap umat yang semata-mata mencari keridloan Allah. Dijelaskan Firman Allah artinya; Hai orang-orang yang beriman, janganlah kamu memakan harta sesamamu dengan jalan yang batil, kecuali dengan jalan perniagaan yang berlaku dengan suka sama suka diantara kamu. Dan janganlab kamu membunub dirimu. Sesunggubnya Allab adalab Maba

8 Sugiyono, 2019. Metode Penelitian Kualitatif Kuantitatif dan R\&D. Bandung: ALFABETA. hlm. 17

${ }_{9}$ Ikhwani Hamdani, Sistem Pasar; Pengawasan Ekonomi (Hisbah) dalam Perspektif Ekonomi Islam (Jakarta: Nur Insani, 2003), hlm. 17 
Penyayang kepadamu ${ }^{10}$. Lakukanlah yang terbaik, berikanlah yang terbaik dari usaha yang optimal untuk mendapatkan hasil yang terbaik. Berkarir disegala bidang sesuai pijakan, dalam usaha mandiri, sebagai profesional kerja organisasi bisnis, pemerintahan, akademisi dan organisasi sosial. Dengan niatan baik menjadikan amalan barokah, memberikan energi positif berfikir jernih dengan kelapangan pandangan hati yang indah. Makna dari Q.S. An-Nisa tentang;" Dan janganlah kamu membunub dirimu. Sesunggubnya Allah adalah Maha Penyayang kepadamu”, Jika membuat usaha mandiri jangan ada niatan yang tidak baik begitu pula dalam karir lainnya, karena hal tersebut dapat membunuh diri sendiri. Pada prinsip dan dasar untuk pemahamannya adalah sederhana, sebagaimana pepatah bijak berpendapat sepandai-pandai menyimpan bangkai akhirnya tercium juga. Sepandai menyembunyikan suatu keburukan akan terbongkar rahasianya. Keluasan pandangan Islam terhadap ekonomi menjadikan sumber yang tidak akan habis digali. Melakukan segala usaha pekerjaan semata-mata mencari keridloan Allah, Insya Allah keberkahan usaha akan terbuka dan kehidupan semakin berkah. Yang keberkahannya datang dari langit dan bumi, begitu luasnya datang dari pintu yang tak terduga.

Mengimplementasi teori kewirausahaan pada dasarnya adalah suatu usaha yang dilakukan melalui pengawasan melekat oleh diri sendiri melalui kreatifitas inovasi berkarakter mencapai kemanfaatan hidup. Orientasi kewirausahaan adalah hasil bukan imbalan dari usahanya, karena kewirausahaan merupakan berjiwa kewirausahaan berorientasi pada kepuasan batin untuk mencapai kesejahteraan dan kebahagiaan. Menelaah teori-teori kewirausahaan menjadikan kebiasaan berperilaku usaha sebagai kebutuhan emosi yang perlu diluapkan dalam tindakan. Mengimplementasi teori kewirausahaan menyatu dalam pemikiran dan batin menjadikan reflek tindakan usaha mandiri tidak menjadi ketergantungan dalam mengupayakan capaian hasil yang optimal, tidak ada keraguan dalam melangkah dengan memperhitungankan kemungkinan kegagalan. Gesit dalam langkah tetapi tidak membesarkan diri, menjadi diri sendiri evaluasi dan adopsi.

Menurut CEO Zappos, Tony Hsieh sukses adalah hidup sesuai dengan nilai-nilai yang diyakininya. Menurutnya nilai dasar personal mendefinisikan siapa individu tersebut sebenarnya dan nilai dasar perusahaan pada akhirnya yang menentukan karakter dan merek produknya $^{11}$.

\footnotetext{
${ }_{10}$ QS. An-Nisa (04): 29

11 https://pelayananpublik.id/2020/04/06/arti-sukses-menurut-para-ahli-tujuanhingga-cara-mencapainya/
} 
Semangat kewirausahaan, Al-Qur'an sangat mengilhami adanya peningkatan kualitas dalam kewirausahaan. Dalam pandangan Al-Qur'an, kerja dan amal adalah yang menentukan posisi dan status seseorang dalam kehidupan. Sebagaimana hal tersebut diungkap dalam Al-Qur'an, Artinya: "Dan masing-masing orang memperoleh derajat-derajat (seimbang) dengan apa yang dikerjakannya. dan Tubanmu tidak lengah dari apa yang mereka kerjakan." ". Bekerja adalah sebagian ibadah dan jihad jika bersikap konsisten terhadap peraturan Allah SWT, kebaikan niat dan tidak melupakan Allah SWT. Menurut Islam setiap muslim berkewajiban untuk bekerja meskipun hasilnya belum dapat dimanfaatkan olehnya dan orang lain. Menjadikan bekerja sebagai upaya beribadah, keindahan akan nampak pada saat aktifitas kerja dan hasil dari apa yang telah dikerjakan. Keindahannya adalah menjadikan apa yang dikerjakan hanya sematamata karna Allah. Bekerja dengan segenap hati dengan pengawasan yang melekat menghasilkan kinerja berkomitmen. Mengupayakan hasil yang terbaik dengan mengeluarkan kemampuan yang optimal berorientasi hasil.

Dengan bekerja, maka akan memberikan perubahan dalam diri dari segala aspek, hal ini sesuai dengan firman Allah SWT: Artinya: "Bagi manusia ada malaikat-malaikat yang selalu mengikutinya bergiliran, di muka dan di belakangnya, mereka menjaganya atas perintah Allah. Sesunggubnya Allah tidak merobah Keadaan sesuatu kaum sehingga mereka merobah keadaan yang ada pada diri mereka sendiri. dan apabila Allah menghendaki keburukan terbadap sesuatu kaum, maka tak ada yang dapat menolaknya; dan sekali-kali tak ada pelindung bagi mereka selain Dia." "13. Melihat ayat tersebut, memberikan pemahaman bahwa ayat tersebut bersifat 'aam (umum) memberikan pemahaman siapa saja yang mencapai keberhasilan dan kesuksesan apabila mereka merubah sebab-sebab kegagalannya yang diawali dengan merumuskan semangat kesuksesan. Dengan pendapat arti lain bahwa seseorang bisa merubah dan berhasil apabila dirinya sendiri merubah dengan istiqomah dan bertanggung jawab apa yang dikerjakan. Tujuan bekerja dalam Islam adalah bukan hanya menghasilkan harta, tetapi mengharap nilai berkah serta sebagai media untuk memakmurkan bumi.. Bekerja secara makro memiliki Multiplayer Efek, yang akan saling memberikan dukungan satu sama lain dalam pergerakan ekonomi global.

Dari teori entrepreneur yang telah banyak dan luas dikemukan para ahli, untuk meraih kesuksesan sebagai modal koreksi perilaku entrepreneur. kesimpulan pendapat untuk memulai menjadi entrepreneur yaitu; (1) Niat dan keyakinan, adalah memiliki kesadaran mengerjakan tugas dengan

${ }^{12}$ Qs. Al-Anam (06): 132

${ }^{13}$ QS. Ar-Ra'd (13): 11 
tanggung jawab dan berusaha menyelesaikan, bahwa ia mampu. Melalui tahapan pekerjaan, tidak ada kata sulit bila dikerjakan dengan seksama, pasti ada solusi menyelesaikan. (2) Sadar akan kemampuan, berorientasi membaca peluang, memiliki dorongan prestasi serta mengenal kelebihan kekurangan diri sendiri. Kesuksesan orang lain bukan pedoman sebagai acuan sukses, tetapi mempelajari proses tahapan kesuksesan yang dapat dibuat kajian. (3) Keinginan belajar, memahami kebutuhan dan layanan terhadap konsumen, dengan mengikuti pergerakan pasar dalam pengadaan produk. Adakalanya produk mendahului akan keinginan kebutuhan layanan konsumen, contohnya produk air minum dalam kemasan pertama dikenalkan dimentahkan konsumen karena dianggap tidak efektif, yang mana konsumen bisa menyediakan kebutuhannya sendiri. Tetapi pada gilirannya konsumen dibuat latah, semua acara tidak ketinggalan menyajikan air minum dalam kemasan dikarenakan efektif. Melalui observasi dijadikan kajian kreatifitas dan inovasi yang menyesuaikan kebutuhan dan layanan yang sesuai pada segmen dan masanya. (4) Komitmen melalui tahapan dan evaluasi untuk menyusun strategi baru, mengontrol kebijakan strategi, menganalisa kesesuaian secara periodik untuk mengefektifkan. Melakukan kontrol untuk memperkecil resiko kebijakan dan dijadikan agenda prioritas. Lebih baik menambah waktu sedikit dalam mempersiapkan kebijakan strategi baru dari pada membuat keputusan yang kurang tepat.

\section{Memulai Menjadi Entrepreneur Pertama, Niat dan keyakinan}

Niat dan keyakinan, adalah memiliki kesadaran mengerjakan tugas dengan tanggung jawab dan berusaha menyelesaikan, bahwa ia mampu. Melalui tahapan pekerjaan, tidak ada kata sulit bila dikerjakan dengan seksama, pasti ada solusi menyelesaikan.

keberanian menuangkan cia-cita harapan akan masa depannya menjadi tujuan sebagai acuan memotifasi diri sendiri. Tidak malu bertanya kepada yang lebih senior dari karir keberhasilanya, keberhasilan orang lain menjadi kekuatan inspirasi. Meredith Mengemukakan bahwa; Para wirausaha adalah orang-orang yang mempunyai kemampuan melihat dan menilai kesempatan-kesempatan bisnis: mengumpulkan sumber-sumber daya yang dibutuhkan guna mengambil keuntungan daripadanya dan mengambil tindakan yang tepat guna memastikan sukses $^{14}$. Mngiemplementasi teori entrepreneur menjadi ukuran untuk memulai menjadi entrepreneur berorentasi pada segala pengetahuan dan

14 Meredith, Geoffrey. 2002. Kewirausahaan, Teori, dan Praktik. Jakarta: CV. Taruna Grafika. hlm: 5 
pengalaman hidup dijadikan pedoman yang mendasar. Dimana pengetahuan dan penglaman hidup benar-benar dijadikan acuan kepribadian untuk bergerak lebih baik.

Mengenali 6 Ciri dan 6 Watak dalam jiwa entrepreneur yang harus dimiliki menurut Meredith, ${ }^{15}$ Ciri-ciri jiwa entrepreneur untuk dipahami yaitu; (1) Percaya diri, seorang entrepreneur memiliki kecakapan beda dan memiliki kelebihan melalui keyakinan yang kuat atas apa yang dilakukan. Hal tersebut bukan berarti tidak memiliki keraguan, tetapi keyakinan kuat selalu dipupuk melalui kajian-kajian serta observasi sebelum melakukan tindakan. Berbekal pengetahuan dan pengalaman hidup menglola produk dengan kretifitasnya menjadi produk inovasi, yang disesuaikan pasar. (2) Berorientasi pada tugas dan hasil, entrepreneur tidak menghitung-hitung watunya dengan balas jasa yang akan didapatkan. Mengoptimalkan hasil dari tugas yang dijalankan, dengan hasil sesuai dan pas-tepat akan kebutuhan layanan produk memberikan kepuasan tersendiri. Dengan adanya kesesuain hasil produk dengan layanannya akan memberikan balas jasa yang lebih tinggi, karena sesuai dengan keinginan/kebutuhan konsumen terpuaskan. (3) Pengambilan resiko, kebranian akan resiko menjadikan pembeda akan penghargaan entrepreneur. Resiko yang terlihat atas orang lain menjadikan etrepreneur unggul. Unggul yang dimaksud adalah entrepreneur memiliki tolak ukur sendiri dalam kreatifitasnya mengelola produk. Berbekal pengetahuan dan pengalaman melihat kegagalan adalah awal dari kesuksesan, dimana dari kegagalan menjadikan wahana pembelajaran untuk melakukan kreatifitas dengan penyesuaianpenyesuaian, tidak ada pemaksaan hasil tetapi menjalani proses dengan keseimbangan yang terukur, selalu melakukan kesesuaian. Kepemimpinan, berbekal pengetahuan dan pengalaman hidup entrepreneur memliki sifat mandiri, yaitu memiliki kemampun memimpin diri sendiri untuk mencapai visinya. Dalam perkembangan usaha menjadikan pemimpin karena memiliki visi yang diikuti dalam organisasi untuk membatu menyelesaikan tugas-tugas yang tidak mungkin bisa dilakukan sendiri. Menjadi pemimpin karena memiliki visi yang dapat diterima oleh pasar dan hanya dia yang dapat merealisasikan visi yang sesuai. (5) Keorisinilan, produk yang dihasilkan berkarakter, memiliki pembeda. Entrepreneur memproses visi menjadi diri sendiri, berkreatifitas berdasar pengetahuan dan pengalamn hidupnya. Produk yang dihasilkan berkarakter memiliki kekhasan sebagai pembeda. (6) Berorientasi ke masa depan, banyak hal menjadi prasarat enrtrepreneur dalam hal ini, setidaknya mengenali layanan yang tepat untuk konsumen. Menjaga

15 Meredith, Geoffrey. 2002. Kewirausahaan, Teori, dan Praktik. Jakarta: CV. Taruna Grafika. hlm: 5-6 
komitmen atas layanan produk yang dihasilkannya, dengan menjaga komitmen memberikan kepuasan berupa rasa aman dan nyaman disetiap transaksi. Menjaga komitmen itu berarti tidak mengejar keutungan sepihak yang akan memiliki daya tawar produk yang meluas dapat diterima dalam kurun waktu yang lama. Setiap produk memiliki umur produk yang sesuai dengan masanya, dengan adanya menjaga komitmen yang baik akan memberikan kontribusi balik berupa informasi evaluasi produk yang positif, maka melalui kreatifitas akan disesuaikan dengan kebutuhan akan layanan produk. Tidak ada pemutusan kerjasama sepihak tetapi selalu kordinasi menghadapi permasalahan-permasalahan pasar, mensejajarkan kepentingan hak dan kewajiban yang seimbang.

Mengenali Watak Jiwa Entrepreneur, untuk dipahami adalah sebagai berikut; (1) Keyakinan, ketidaktergantungan, individualistis, dan optimisme, kekuatan kayakinan akan kesuksesan visinya terkadang membuat kebimbangan pendukung organisasi disekitarnya. Tetapi tidak mematahkan impian cita-cita berusaha dan tetap gigih dalam meraih keberhasilan. Berbekal pengetahuan dan pengalaman hidup menjadikan kegagalan menjadi guru yang terbaik. Tekat yang kuat membuat seolaholah individualistis, kekuatan keyakinan dan optimisme membentuk daya tahan entrepreneur menjadi handal. (2) Kebutuhan untuk berprestasi, berorientasi laba, ketekunan dan ketabahan, tekad kerja keras, mempunyai dorongan kuat, energetik dan inisiatif. Kekuatan inspirasi dari keberhasilan orang lain mmbuahkan visi sebagai acuan keberhasilan. Dari inpirasi menjadikan kekuatan yang dahsyat. Dengan ketekunan dan ketabahan melalui berbagai tantangan, kesulitan membakar tekat bekerja keras. Berbekal dorongan yang kuat membuat berbagai kemampuan optimal. Tidak terbatas waktu menjadikan langkah semakin energik, berusaha berkreasi menjadikan pribadi yang banyak melakukan strategi dan selalu inisiatif. Besarnya dorongan keberhasilan menjadikan suatu kebutuhan untuk selalu berkarya dengan kreatifitas yang memiliki keunggulan dalam berprestasi. (3) Kemampuan untuk mengambil resiko yang wajar dan suka tantangan, dengan bekal dan pengalaman hidup memiliki kemampuan mengambil keputusan yang tepat. Dengan kemampuan yang sudah bersinergi, memiliki kemampuan menganalisa dalam menghidari resiko, tetapi selalu suka membuat langkah beda untuk menghasilkan produk yang beda. Untuk menyelesaikan karya menjadikan tantangan baru yang harus diproses beda agar memiliki hasil yang berkarakter. (4) Perilaku sebagai pemimpin, bergaul dengan orang lain, menanggapi saran-saran dan kritik, jam terbang yang tinggi karena tingkat menyelesaikan masalah beda dan sudah teruji, adanya ketergantungan dalam organisasi adalah wajar karena menginginkan suatu keputusan yang tepat. Seringnya menghadapi permasalahan dan 
adanya kesanggupan menyelesaikan menjadi pribadi yang solotif, sehingga mudah diterima dalam pergaulan. Kritik dan saran dijadikan umpan balik dalam menyelesaikan tugas, untuk menyempurnakan hasil. (5) Inovatif dan kreatif serta fleksibel, aktifitas kebiasaan menjadikan hasil produk yang diselesaikan inovatif. Selalu mencoba hal baru menjadikan kebutuhan dalam kreatifitas. Tuntutan pemenuhan pasar mebuat pribadi menjadi fleksibel, karena menginginkan layanan yang sesuai pas-tepat dengan pasar, maka dianggap penting adanya penyesuaian-penyesuain yang fleksibel. (6) Pandangan ke depan, perspektif. Seorang entreprenur hendaknya memiliki kemampuan menatap masa depan dengan lebih optimis. Melihat ke depan dengan berfikir dan berusaha. Usaha memanfaatkan peluang dengan penuh perhitungan.

\section{Kedua, Sadar akan kemampuan}

Sadar akan kemampuan, berorientasi membaca peluang, memiliki dorongan prestasi serta mengenal kelebihan kekurangan diri sendiri. Kesuksesan orang lain bukan pedoman sebagai acuan sukses, tetapi mempelajari proses tahapan kesuksesan yang dapat dibuat kajian. Mengembangkan ide kreatif sedemikian rupa sehingga ide tersebut memiliki nilai pasar yang kita sebut sebagai inovasi. Intuisi akan gagasan bergerak sesuai pergerakan pasar pada masanya, seolah memiliki ritme nada yang tepat. Hal tersebut tergerak karena feeling, terlatihnya jiwa entrepreneur melalui langkah stretegi yang menyajikan produk inovasi. Baik buruk produk dari hasil kreasi pada akhirnya pasar yang memberikan penilaiannya. Inti dari bisnis adalah layanan, kemampuan memberikan layanan yang sesuai pas-tepat pada porsi yang diinginkan konsumen. Kesuksesan merupakan harapan dari semua orang, tetapi bergerak dan pergerakannya yang membuat ribet karena belum terbiasa, tidak mau melakukan. Pada dasarnya semua berkeinginan aman dan nyaman yang terkadang tidak sedikit menyalah artikan. Aman nyaman terkadang hanyalah pandangan karena hal tersebut harus terbelikan dengan syarat yang sesuai, syarat yang sesuai inilah yang jarang terlihat, kecuali dari pelaku entrepreneur membuka diri.

Kunci kesuksesan karir dapat tercapai ada 12, Menurut Oltesvig, ${ }^{16}$ antara lain: (1) Mengelola karir Anda, Andalah yang bertanggung jawab untuk mengelola karir anda sendiri, sebagai profesional yang berkualitas, anda harus mengendalikan karir anda untuk mengimbangi dengan perubahan yang terjadi. (2) Berani bertanggung jawab, jangan pernah bergantung kepada bawahan anda untuk kesuksesan karir anda. Anda

16 Oltesvig, John, 2006. "12 Keys to Career Success", Quality Progress, Hal 22 
harus berani mengambil tanggung jawab untuk mengelola karir anda. (3) Mulai hari ini, tidak peduli seberapa burukpun karir anda di masa lalu, karena selalu ada harapan untuk masa depan jika anda ingin berbuat sesuatu yang benar untuk karir anda dan memulai perubahan hari ini. (4) Mengartikan kesuksesan bagi Anda, mendefenisikan kesuksesan dan menyesuaikan tujuan yang layak bagi anda sangatlah penting dan perlu untuk dilakukan sekarang juga, sehingga mulai pikirkan arti dari sukses bagi anda secara pribadi, dan anda pun akan segera mendapatkan kesuksesan tersebut. (5) Memulai dari dasar, memulai karir dari sebuah perusahaan kecil merupakan jalan yang baik untuk mendapatkan pengalaman di dunia kerja. Orang yang tidak pernah melakukan kesalahan adalah orang yang tidak produktif, sehingga jangan takut untuk mencoba hal yang baru. (6) Menciptakan nilai, untuk mencapai kesuksesan di dalam suatu perusahaan, anda harus menciptakan nilai. (7) Tegas terhadap diri sendiri, siapa saja yang merasa hidup itu mudah, mereka adalah orang-orang yang tidak pernah merasakan saat-saat sulit di dalam hidupnya. Sifat tegas terhadap diri sendiri dapat menghindarkan kita dari keadaan sulit dalam hidup, tegas berarti memiliki kebijakan yang kuat. (8) Fokus, selalu fokus dengan apa yang telah direncanakan sebelumnya, sehingga ini akan membantu anda untuk meningkatkan performa kerja anda. (9). Menjadi seorang penulis, kunci kesuksesan lainnnya adalah dengan menjadi penulis, cobalah untuk menulis sebuah artikel dan diterbitkan kedalam sebuah jurnal nasional, sehingga banyak orang yang akan mengetahui siapa anda dan perusahaan tempat anda bekerja. (10) Gunakan kemunduran sebagai batu loncatan, anda dapat merencanakan karir anda di masa depan ketika anda mendapat PHK (Pemutusan Hubungan Kerja), ataupun saat anda memutuskan untuk berhenti bekerja di suatu perusahaan (11) Terlatih untuk sukses, sebuah pendidikan dasar merupakan elemen terpenting dari kesuksesan karir, sehingga biasakanlah diri anda agar terlatih untuk sukses (12) Mempertimbangkan perusahaan masa lalu, mungkin anda telah keluar dari sebuah perusahaan, akan tetapi suatu saat setelah sekian lama anda bekerja ditempat lain, mungkin saja ada peluang untuk bekerja kembali di perusahaan lama anda dengan posisi yang lebih baik. Dari duabelas penjelasan diatas akan memberikan pembelajaran yang sangat berharga untuk dipahami. Membuat suatu keputusan untuk kebijakn diperlukan pertimbangan yang matang, mengulas ulang permasalahan untuk mempermudah membuat keputusan yang baik dan bijak.

\section{Ketiga, Keinginan belajar}

Keinginan belajar, memahami kebutuhan dan layanan terhadap konsumen, dengan mengikuti pergerakan pasar dalam pengadaan 
produk. Adakalanya produk mendahului akan keinginan kebutuhan layanan konsumen, contohnya produk air minum dalam kemasan pertama dikenalkan dimentahkan konsumen karena dianggap tidak efektif, yang mana konsumen bisa menyediakan kebutuhannya sendiri. Tetapi pada gilirannya konsumen dibuat latah, semua acara tidak ketinggalan menyajikan air minum dalam kemasan dikarenakan efektif. Melalui observasi dijadikan kajian kreatifitas dan inovasi yang menyesuaikan kebutuhan dan layanan yang sesuai pada segmen dan masanya., memahami kebutuhan dan layanan terhadap konsumen, dengan mengikuti pergerakan pasar dalam pengadaan produk. Adakalanya produk mendahului akan keinginan kebutuhan layanan konsumen, contohnya produk air minum dalam kemasan pertama dikenalkan dimentahkan konsumen karena dianggap tidak efektif, yang mana konsumen bisa menyediakan kebutuhannya sendiri. Tetapi pada gilirannya konsumen dibuat latah, semua acara tidak ketinggalan menyajikan air minum dalam kemasan dikarenakan efektif. Melalui observasi dijadikan kajian kreatifitas dan inovasi yang menyesuaikan kebutuhan dan layanan yang sesuai pada segmen dan masanya.

Peran dan fungsi kewirausahaan mendasar yang mampu mempengaruhi perilaku yang mengarah pengembangan kewirausahaan, menurur Irhan Fahmi. 2013; Mampu memberi semangat dan motivasi, Mampu mewujudkan mimpi, Mampu memberikan inspirasi, Memberikan nilai positif dalam pembangunan ${ }^{17}$. Belajar menjadi pemimpin diawali dengan kemampuan memimipin diri sendiri.

\section{Keempat, Komitmen melalui tahapan dan evaluasi}

Komitmen melalui tahapan dan evaluasi untuk menyusun strategi baru, mengontrol kebijakan strategi, menganalisa kesesuaian secara periodik untuk mengefektifkan. Melakukan kontrol untuk memperkecil resiko kebijakan dan dijadikan agenda prioritas. Lebih baik menambah waktu sedikit dalam mempersiapkan kebijakan strategi baru dari pada membuat keputusan yang kurang tepat.

Seorang Entrepreneur berani mengambil resiko yang telah diperhitungkan. Oleh karena mereka sadar akan resiko, maka kegagalan dan resiko yang ditanggung bukan lagi menjadi alasan untuk berhenti mencoba. Menurut Wu, beberapa kompetensi yang harus dimiliki oleh seorang wirausaha adalah: Kemampuan menganalisis secara sistematis, Kemampuan untuk mengambil peluang dan mengelola sumber yang ada, Kemampuan untuk menemukan kebutuhan internal dan eksternal dari konsumen, Kemampuan untuk belajar dan meningkatkan kompetensi

${ }^{17}$ Irham Fahmi, 2013. Kewirausahaan, Bandung: Alfabeta. Hlm: 3 
yang dimiliki, Kemampuan berkomunikasi ${ }^{18}$. Dengan komitmen melalui tahapan akan memiliki kemampuan menganalisa permasalahan dan mengevaluasi.

\section{KESIMPULAN}

Melakukan segala usaha pekerjaan semata-mata mencari keridloan Allah, Insya Allah keberkahan usaha akan terbuka dan kehidupan semakin berkah. Mengimplementasi teori kewirausahaan pada dasarnya adalah suatu usaha yang dilakukan melalui pengawasan melekat oleh diri sendiri melalui kreatifitas inovasi berkarakter mencapai kemanfaatan hidup. Orientasi kewirausahaan adalah hasil bukan imbalan dari usahanya, berorientasi pada kepuasan batin untuk mencapai kesejahteraan dan kebahagiaan. Kepuasan batin berupa kebanggan ketika produk yang dihasilkan dapat diterima oleh konsumen. Ketika produk dikosumsi kosumen beserta kemanfaatanya, keberkahannya akan diterima sebagai amalan kebaikan yang pahalanya tidak terputus selama kemanfaatanya masih berjalan.

Mencapai keberhasilan dan kesuksesan apabila mereka merubah sebab-sebab kegagalannya yang diawali dengan merumuskan semangat kesuksesan. Dengan pendapat arti lain, bahwa seseorang bisa merubah dan berhasil apabila dirinya sendiri merubah dengan istiqomah dan bertanggung jawab apa yang dikerjakan. Berorientasi pada segala pengetahuan dan pengalaman hidup dijadikan pedoman yang mendasar. Dimana pengetahuan dan penglaman hidup benar-benar dijadikan acuan kepribadian untuk bergerak lebih baik. Selalu mengembangkan ide gagasan baru dalam kreatifitasnya, menyerasikan niat dan keyakinan dengan meningkatkan kekuatan melalui pengetahuan berorentasi kebutuhan pasar dalam mengelola produk. Hasil kreatifitas berupa produk yang memiliki kesesuain layanan pada segmen dan masanya dikenal sebagai inovasi produk.

Memulai menjadi entrepreneur mempersiapkan koreksi perilaku meliputi kesimpulan pendapat yaitu; (1) Niat dan keyakinan, memiliki kesadaran mengerjakan tugas dengan tanggung jawab dan berusaha menyelesaikan, bahwa ada kemampuan yang belum terungkap yang harus diusahakan lagi. Keyakinan yang kuat akan memupuk niatan, membawa kesadaran untuk berbuat, bekerja dan mengerjakan. Niat dan keyakinan akan membuka rahasia tabir dalam proses berjalan. (2) Sadar akan kemampuan, berorientasi membaca peluang, memiliki dorongan prestasi,

${ }^{18}$ Fithri, S., dan Amanda, N. (2012). Analisis Kompetensi kewirausabaan Industri Kecil Suku Cadang di Kota Padang. Skripsi Manajemen pada FT UNPAS Padang: diterbitkan .hlm. 280. 
mempelajari proses tahapan kesuksesan yang dapat dibuat kajian analisa yang handal. (3) keinginan belajar, memahami kebutuhan dan layanan terhadap konsumen, mengikuti pergerakan pasar dalam orintasi kesesuaian produk baru. (4) Komitmen melalui tahapan dan evaluasi untuk menyusun strategi baru, mengontrol kebijakan strategi, menganalisa kesesuaian secara periodik untuk mengefektifkan dan memperkecil resiko.

\section{DAFTAR PUSTAKA}

Al-Qardhawi, Yusuf. Norma dan Etika Ekonomi Islam. Jakarta: Gema Insani Press. 2019.

Al-Qur'an dan Terjemahnya.

Arikunto. Metode Penelitian Kualitatif, Jakarta: Bumi Aksara. 2006.

Buchari, Alma. Kewirausabaan. Bandung: Alfabeta. 2006.

Cat Alford. Tony Robbins' 10 Tips for Living Rich. Time.com https://goo.gl/s1uIrN. 12 Maret 2016.

Fithri, S., dan Amanda, N. (2012). Analisis Kompetensi kewirausabaan Industri Kecil Suku Cadang di Kota Padang. Skripsi Manajemen pada FT UNPAS Padang: diterbitkan.

http:/ / ciputrauceo.net/blog/2013/10/5/empat-karakter-entreprenuer http://thez-afif.blogspot.com/2011/10/konsep-dasar-kewirausahaan.html https://marketing.co.id/karakter-wajib-bagi-calon-enterpreneur-sukses/ https://media.neliti.com/media/publications/218030-konsep-dasarkewirausahaan-dan-proses-ke.pdf

https://pelayananpublik.id/2020/04/06/arti-sukses-menurut-para-ablitujuan-bingg-acara-mencapainyal

https://www.finansialku.com/10-tips-tony-robbins-untuk-menjadiwirausahawan-sukeses-1/

Irham Fahmi. Kewirausahaan, Bandung : Alfabeta. 2013.

Iwantono, Sutrisno. Kiat Sukses Berwirausaha. Jakarta: PT Grasindo. 2002. Kasmir. Kewirausahaan. Jakarta: PT Raja Grafindo Persada. 2007.

Meredith, Geoffrey. Kewirausahaan, Teori, dan Praktik. Jakarta: CV. Taruna Grafika. 2002.

Mursobah, Ahmad. 2012. Konsep Dasar Kewirausabaan. http://cobah-ajah. blogspot.co.id/2012/05/konsep-dasar-kewirausahaan.html.

Oltesvig, John, "12 Keys to Career Success”, Quality Progress, 2006.

Sarwono, Jonathan. Metode Penelitian Kuantitatif dan Kualitatif. Yogyakarta: Graha Ilmu. 2006.

Sugiyono. Metode Penelitian Kualitatif Kuantitatif dan R\&D. Bandung: ALFABETA. 2019. 
Suryana. Kewirausabaan: Pedoman Praktis, kiat dan Proses Menuju Sukses. Jakarta: Salemba Empat. 2003.

Zulfiria dan Arif, Zaenal. Membangun Kewirausabaan (Entrepreneurship) Qur'ani di Perguruan Tinggi. Rausyan Fikr. Vol. 14 No. 1 Maret 2018. 